\title{
Obsolete pesticides in Saudi Arabia: problems, prevention and disposal
}

\begin{abstract}
Expired and deteriorated stocks of pesticides are present in most developing countries. Those products no longer can be used to control the intended target pests as recommended on the label. The existence of obsolete pesticides can be due to many reasons such as inadequate storage facilities or storage containers, in addition to poor stock management and record keeping. Banning the pesticides while in storage and poor assessment of pesticide requirements, such as inability to forecast pest outbreaks, may cause prolonged storage of products with short shelf lives. Furthermore, marketing systems with aggressive profit motive by vendors may lead to accumulation of expired pesticides. These stocks are often stored in poor conditions, which may cause damage and leaking of the containers with obsolete and dangerous pesticides that may pose a threat to human health and the environment. Disposal of obsolete pesticides in a safe and environmentally sound manner are only available in a few newly industrialized countries, but the developing countries do not have such facilities. Therefore, the recommended disposal method for stockpiles of obsolete pesticides in developing countries should systematically undergo various steps. These would include inventory, repackaging, safe guarding of the pesticides and then shipment of the pesticides to a country that has appropriate hazardous waste incineration facilities. This global environmental issue is a result of decades of mishandling. It is most dramatic in the developing world which lack the resources and funding for remediation of the hazardous waste sites and obsolete pesticides. Conservative estimates find well over 500,000 tons of obsolete pesticides in developing countries, with 50,000 to 100,000 tons just in Africa alone. The collaborative Programme on the Prevention and Disposal of Obsolete Pesticides, established by the Food and Agricultural Organization of the United Nations (FAO) in 1994, underlines the urgency and importance of a concerted international effort to solve this problem.
\end{abstract}

Keywords: obsolete pesticides, organochlorine, saudi arabia
Volume I Issue 2 - 2015

Mohamad Jamal Hajjar
King Faisal University, Saudi Arabia

Correspondence: Mohamad Jamal Hajjar, College of Agricultural and Food Sciences, King Faisal University, Al- Hassa 31982, Saudi Arabia, Tel 00966559 I764I2,

Email jamalnoura@yahoo.com

Received: March 16, 2015 | Published: May 28, 2015
Abbreviations: FAO, food and agricultural organization; WHO, world health organization; HCB, hexa-chloro-benzene; POPs, persisted organic pollutants; JMPR, joint fao/who meeting on pesticide residues; UNEP, united nations environmental program

\section{Current situation of pesticides}

There are presently hundreds of highly hazardous pesticides being used. These include:

a) 118 active ingredients that are endocrine-disruptors

b) 60 active ingredients that are classified as carcinogenic to some degree

c) 129 pesticides that are defined as extremely or highly hazardous by the World Health Organization (WHO Class Ia or Ib)

d) 111 pesticides that are organic pollutants

\section{When pesticides become obsolete}

Obsolete pesticides are defined by the FAO as stockpiled pesticides that can no longer be used for their original purpose or any other purpose and therefore require disposal. The causes of pesticides to become obsolete commonly include the following: ${ }^{1-3}$
A. The product has been banned and withdrawn from markets due to health or environmental reasons;

B. Improper or prolonged storage of the product has caused deterioration to the product and can no longer be used according to the recommended use instructions on the label, and cannot easily be modified to become usable again; or

C. The pesticide is considered as obsolete if the formulation or ingredients of the product is not suitable for its original use and cannot be used for another purpose.

A pesticide is considered as deteriorated when it is physically and/ or chemically changed. Such alterations in the product may result in phyto toxic effects on the target crop, or an unacceptable hazard to human health or the environment. The deterioration of the product may result in degradation of the active ingredient and/or physical and chemical changes that lead to unacceptable loss of biological efficacy. In addition the changes in its physical properties may be to such an extent that the product no longer can be applied with standard or stipulated application equipment. Obsolete pesticides are sometimes referred to as two other terms to reflect the description of the case. Some publications refer to obsolete pesticides as pesticide waste while others refer to them as unwanted pesticides. ${ }^{4}$ However, the two expressions possess a broader definition than the term of obsolete 
pesticides. When the product is considered as obsolete, that means it definitely cannot be used any longer and requires disposal. On the other hand, this definition of obsolete pesticides also cover pesticides to ck piles that, in principle, could still be used, and are regarded as unwanted by their owner. This could be due to no longer having the pest problem, because logistical constraints on pesticide distribution, or because the formulation is not suitable for the available application equipment. Those products may still be in good condition, but there is no immediate use for them and it can be used in other useable circumstances without possessing any compromising environmental or occupational safety. Such products should not be considered as obsolete so long as it has to the impediments hindering their use can be solved. However, the consequences of prolonged storage of the stocks which are still usable may become obsolete, resulting in increased risk to the environment and humans.

The shelf-life of many or most pesticides normally is two years from the date of release. The manufacturing companies guarantee the quality of the product if it is stored according to the storing conditions (e.g., temperature, humidity and direct sunlight) as precisely stated on the label. Pesticides can often be stored for much longer than their indicated shelf-life on the label since storage periods beyond the shelf-life do not automatically mean that such products have degraded beyond usability. Analytical results of five- to seven-year-old stocks of organophosphates showed that the products were still usable. However, the opposite may also occur when the product is stored under extremely high temperatures, exposed to direct sunlight and/or strong temperature fluctuations that may accelerate deterioration, making the product unusable before expiration date of its shelf-life. For example, a temperature rise of $10^{\circ} \mathrm{C}$ may increase the decomposition rate by a factor of two or three (GIFAP, 1985).

Sometimes the deterioration of the product as a result of physical changes is easily identified from the original. The original products are usually clear liquid formulations, and the physical deterioration may result in forming flakes, crystals or an emulsion. The powder pesticide formulations may have solidified after becoming damp. However, oftentimes it is more difficult to distinguish the deteriorated and physically changed products from those whose chemical properties have not changed, especially if the visible physical properties remain unchanged. Therefore, chemical analysis is necessary to establish whether the product is still usable. The FAO set and published guidance on permitted tolerances for active ingredient contents, impurities and physical properties. Moreover, a decline in active ingredient concentration does not imply the product has become unusable. If the degradation products of the active ingredient do not increase the product's toxicity beyond acceptable margins and physical properties don't change, the decline in active ingredient may be compensated by a proportional increase in application volume.

\section{Accumulation of obsolete pesticides}

Many factors may have contributed to the formation of present obsolete pesticide stockpiles. Banning pesticides could be the main factor contributing the most to stockpile accumulation. Poor stock management (e.g., due to inadequate stores, insufficient storage capacity, and staff not trained in stock management and handling during transport) may also contribute to stockpile accumulation. Also, the product may not be suitable because of inappropriate active ingredient or formulation, package size or poor container quality, missing or incomplete labels; insufficient communication between the aid agency and recipient country, or fraudulent practices of unreliable suppliers. Inaccurate assessment of how much pesticide is required may result in an accumulation of excess pesticides. In addition, overstocking of products with a short shelf-life cause an accumulation of obsolete pesticides. Furthermore, outside interests (e.g., the commercial interests of the pesticide industry) and other hidden factors may play an important role in the accumulation of pesticides in developing countries.

\section{Contamination of organochlorine pesticides in environment and food}

The organochlorine pesticides, such as DDT, were the most widely used insecticides in the period of 1945-1980. They were highly efficient in controlling insects and pests on field crops and other horticulture plants. In addition, they were used to control public health vectors such as mosquitoes. In fact these chemicals had the capability to persist in water and to associate well with vegetation for several weeks. It has been shown that they are very persistent in the environment and may remain in soil for 10 to 15 years after application. Therefore, the intensive agricultural applications of these organochlorine products resulted in global contamination, which concerned scientists, farmers and decision makers. Such persistence combined with a high partition coefficient $(\log \mathrm{KOW}=4.89-6.91)$ provides the necessary conditions for DDT to bio accumulate in organisms. ${ }^{5}$ In Mali, the organochlorine insecticides were detected in soils of cotton growing area showing that $77 \%$ of these soil samples were contaminated with DDT or its break down products in addition to endosulfan. ${ }^{6}$ Endosulfan was the most common insecticide used on cotton and is found in most cotton crop soil samples. A range of insecticides have been detected in surface and groundwater sources, including: lindane, endosulfan, dieldrin, $\mathrm{p}, \mathrm{pDDT}$ and $\mathrm{p}, \mathrm{pDDT}$. In a long-term agricultural experiment carried out in the UK by Meijer et al. ${ }^{7}$ the highest concentrations of organochlorine insecticides found in soil were $\gamma-\mathrm{HCH}$, dieldrin and p,p DDE with levels ranging from 0.1 to $10 \mathrm{ngg}^{-1}$ based on soil dried weight. Also, the results showed a significant decline in the concentrations of pesticides detected in soil samples collected and analyzed during the late 1960's to 1990's.

In Egypt, Dogheim et al. ${ }^{8}$ detected the levels of organochlorine in soil samples collected from the Kafer El-Zayat governorate. DDT was found in all soil samples at high levels but the levels of HCH were negligible. However $\mathrm{HCH}$ and DDT were found in all water samples, the highest levels were detected in ground water samples followed by Nile river water samples and last tap water samples. In further experiments, human milk samples were taken at three different intervals in 1987, 1990 and 1996. Most of the organochlorine insecticides were detected in the 1987 and 1990 milk samples but not found in 1996 samples. This was attributed to the fact these insecticides were banned from use in Syria in 1984. Information on the contamination of organochlorine insecticides in soils or water is very rare country wide. An investigation was conducted in the Damascus countryside, in which 6-sets of soil samples were collected over a period of 11 months from agricultural lands under intensive cultivation. These samples were taken from two depths (i.e. $0-10 \mathrm{~cm}$ and $30-45$ ). The results revealed the presence of chlordane at $0.2-1.29$, lindane at 0.07 -0.1 , and endrin at $0.06 \mathrm{mgg}^{-1}$. Mostly absent were aldrin at 0.03 0.013 and DDT at $0.13-0.35 \mathrm{mgkg}^{-1}$. The samples of ground water 
collected from the studied area did not contain detectable levels of DDT or dieldrin, but lindane was detected at levels ranged between 0.042 and $0.025 \mathrm{mgL}^{-1} .{ }^{9}$ In Saudi Arabia, Al-Wabel et al. ${ }^{10}$ monitored the pesticide residues in soil samples collected from 15 regions. The organo-chlorine pesticides were among the pesticides observed ppDDT at levels of 0.08-0.525, pp DDE at 0.1-0.525, and lindane at $0.290-0.394 \mathrm{mgkg}^{-1}$. Also the ground water samples disclosed that the most detected pesticides in water samples were the dimethoate, organo-phosphorous pesticides, which were observed in $86.66 \%$ of studied regions. The pp DDT residues were detected only in Gazan region at a level of $0.107 \mathrm{mgL}^{-1}$ and pp DDE in Wadi Al- Dawaser and Gazan regions at levels of 0.0056 and $0.090 \mathrm{mgL}^{-1}$, respectively. In Jordan, the use of the aldrin, dieldrin, endrin, heptachlor and hexachloro-benzene (HCB) has been banned officially in 1981 and DDT in 1995. Ahmad et al. ${ }^{11}$ found the organo-chlorine pesticide residues in 233 dairy product samples (i.e., milk, butter, cheese, labaneh and yoghurt) collected from Jordan Markets. The results indicated that 9\%, $8.5 \%, 6 \%$ and $2.1 \%$ of the examined samples were contaminated with beta-HCH, pp'-DDE, alpha-HCH and gamma-HCH, respectively. Heptachlor and alpha-endosulfan were only present in less than $2 \%$ of the analyzed samples. In another study, Ahmad et al. ${ }^{11}$ detected the organo-chlorine pesticide residues in 519 samples of eggs, chicken and meat (i.e., lamb and beef) collected from Jordan market. The results indicated that $28 \%, 20 \%$ and $49 \%$ of the examined eggs, chicken and meat samples, respectively, were contaminated with HCHs and DDTs. On the other hand, heptachlor, heptachlor epoxide, HCB, aldrin and endrin compounds were detected only in less than $7 \%$ of the analyzed samples.

Food is one of the most important sources of human exposure to residues of pesticides. Although there residues of organochlorine insecticides in domestic animals have declined steadily over the past 20 years since the Stockholm convention has decided to ban and stop production of all persisted organic pollutants (POPs). But DDT and its metabolites have been detected in most foods and food stuffs samples all over the world. Survey of domestic animal fats and eggs in Ontario, Canada, showed that, DDE was detected in $21 \%$ of the analyzed samples, and was second most frequently insecticide found in the samples with a maximum concentration of $0.410 \mathrm{mgkg}^{-1}$. In Spain, survey of pesticides residues in meat and meat products revealed that, $83 \%$ of lamb samples contained at least one of the DDT metabolites products, with mean residues of $25 \mathrm{ppb}$. In Egypt an average of $76.25 \mathrm{ppb}$ of pp DDE was detected in fish samples. In Vietnam, DDT was the most common organo-chlorine product that was detected in food stuffs, with mean residue concentrations of 3.2 and $2.0 \mu \mathrm{g}$ per gm fat in meat and fish, respectively, the estimated daily intake of DDT and its metabolites in Vietnam was $19 \mu \mathrm{g} /$ person/day. In India, the average residues detected in meat and fish were 1.0 and $1.1 \mu \mathrm{g}$ per gm fat, respectively, with an estimated daily intake of $48 \mu \mathrm{g} /$ person/ day for the DDT and its metabolites. ${ }^{12}$ DDT has been also detected in human breast milk in a general survey of 16 separate compounds in the breast milk of lactating mothers in four remote villages in Papua, New Guinea; DDT was detected in $100 \%$ of samples. DDT was also detected in the breast milk of Egyptian women, with an average total DDT detection level of 57.59ppb and an estimated daily intake of total DDT for breast feeding infants of $6.90 \mu \mathrm{g} / \mathrm{kg}$ body weight / day, although it is lower than the acceptable daily intake of $20.0 \mu \mathrm{g} /$ $\mathrm{kg}$ body weight recommended by the Joint FAO/WHO Meeting on Pesticide Residues (JMPR), but its continuing presence raises serious concerns regarding potential effects on developing infants (United Nations Environmental Program (UNEP) 1995).

\section{Hazards of obsolete pesticides}

Poor stock management and inadequate stores with long storing period may led to Leaking drums and torn bags, which can seriously affect the occupational health of staff working at the storage site and of others who usually used to come to store. ${ }^{13}$ Leakage of obsolete pesticides often poses a broader general danger to public health and the environment. Leakage of pesticides into ground Contaminate the groundwater or soil which can occur through seepage or runoff during heavy rains. Poisoning of people or animals can occur through direct and indirect contact with the product, inhalation of vapors, drinking of contaminated water, or eating of contaminated food. In addition fire hazard, which may occurs as result of poor maintenance of stores and/or management of stocks. The environmental contamination caused by fires can be widespread, because the pesticides in stores that have caught fire will be converted to vapors and fume. FAO stated the factors that determining the level of hazard could be cause by stockpile of obsolete pesticides. ${ }^{14}$

i. Degree of leakage is fully depends on the quantity of pesticides, the condition of containers and packaging.

ii. The place of storage (inside or outside a store) and the degree of impermeability of floor material of the storage site

iii. The behavior of the product in the environment (persistence, mobility in soil, solubility in water, volatility)

iv. The location of the storage site and the distance from the urban areas

v. The groundwater level and proximity of the storage site to water bodies.

\section{Magnitude of obsolete pesticides in the world}

According to FAO, a conservative estimation find well over 500 000 tons of obsolete pesticides in developing countries, 50000 to 100 000 tons of which in Africa alone.

a) Africa and Near East: more than 100000 tonnes

b) Asia: more than 100000 tonnes

c) Poland: 60000 tonnes

d) Ukraine: 23000 tonnes

e) Latin America: unknown

\section{Obsolete pesticides in saudi arabia}

According to FAO summery of known obsolete pesticide stocks published in July 2000, ${ }^{15}$ in Saudi Arabia there are around 241 ton of obsolete insecticides and 24.8 tons of them are POPs insecticides. However, the Table 1 below illustrates the inventory of obsolete pesticides presented in the stores of the ministry of agriculture in Saudi Arabia, which are estimated of 84,127liter of liquid formulation and143, $776 \mathrm{~kg}$ of solid formula (WP). Those pesticides are existed in southern, western, eastern, northern and central regions in addition to the locust center (Table 1). 
Table I The inventory of obsolete pesticides in Saudi Arabia

\begin{tabular}{|c|c|c|c|c|c|c|c|c|c|c|c|c|}
\hline $\begin{array}{l}\text { Sitel } \\
\text { Store } \\
\text { Affect- } \\
\text { ed }\end{array}$ & $\begin{array}{l}\text { Com- } \\
\text { mon } \\
\text { Name }\end{array}$ & $\begin{array}{l}\text { Com- } \\
\text { mercial } \\
\text { Name }\end{array}$ & $\begin{array}{l}\text { Formu- } \\
\text { lation }\end{array}$ & $\begin{array}{l}\text { Chem- } \\
\text { ical } \\
\text { Group }\end{array}$ & $\begin{array}{l}\text { Toxicity } \\
\text { Group } \\
\text { (WHO) }\end{array}$ & $\begin{array}{l}\text { Type of } \\
\text { Contain- } \\
\text { er }\end{array}$ & $\begin{array}{l}\text { Condi- } \\
\text { tion of } \\
\text { Con- } \\
\text { tainer }\end{array}$ & $\begin{array}{l}\text { Num- } \\
\text { ber of } \\
\text { Con- } \\
\text { tainers }\end{array}$ & $\begin{array}{l}\text { Quanti- } \\
\text { ty Kgs }\end{array}$ & $\begin{array}{l}\text { Quanti- } \\
\text { ty Lts }\end{array}$ & $\begin{array}{l}\text { Year } \\
\text { Manu- } \\
\text { factured }\end{array}$ & $\begin{array}{l}\text { Coun- } \\
\text { try, } \\
\text { Manu- } \\
\text { facturer, } \\
\text { Donor, } \\
\text { Source }\end{array}$ \\
\hline $\begin{array}{l}\text { Southern } \\
\text { Region }\end{array}$ & $\begin{array}{l}\text { Malathi- } \\
\text { on }\end{array}$ & $\begin{array}{l}\text { Malathi- } \\
\text { on } 98 \%\end{array}$ & ULV & OP & III & 200 & Very old & 103 & 0 & 20575 & 1978 & $\begin{array}{l}\text { Italy \& } \\
\text { Germany }\end{array}$ \\
\hline $\begin{array}{l}\text { Western } \\
\text { Region }\end{array}$ & Mixture & $\begin{array}{l}\text { Fulaton } \\
93 \%\end{array}$ & ULV & $\begin{array}{l}\text { OP + } \\
\text { Carb }\end{array}$ & II & 20 & Very old & 96 & 0 & 1910 & 1988 & $\begin{array}{l}\text { Bayer- } \\
\text { Germany }\end{array}$ \\
\hline $\begin{array}{l}\text { Central } \\
\text { Region }\end{array}$ & $\begin{array}{l}\text { Malathi- } \\
\text { on }\end{array}$ & $\begin{array}{l}\text { Malathi- } \\
\text { on } 96 \%\end{array}$ & ULV & OP & III & 15 & Very old & 1134 & 0 & 17000 & 1988 & $\begin{array}{l}\text { Cynamid- } \\
\text { USA }\end{array}$ \\
\hline $\begin{array}{l}\text { Eastern } \\
\text { Region }\end{array}$ & $\begin{array}{l}\text { Malathi- } \\
\text { on }\end{array}$ & $\begin{array}{l}\text { Malathi- } \\
\text { on }\end{array}$ & ULV & OP & III & 200 & Very old & 28 & 0 & 5584 & 1988 & $\begin{array}{l}\text { Cynamid- } \\
\text { USA }\end{array}$ \\
\hline $\begin{array}{l}\text { Western } \\
\text { Region }\end{array}$ & $\begin{array}{l}\text { Malathi- } \\
\text { on }\end{array}$ & $\begin{array}{l}\text { Malathi- } \\
\text { on } 96 \%\end{array}$ & ULV & OP & III & 204 & Very old & 7 & 0 & 1225 & 1988 & $\begin{array}{l}\text { Cynamid- } \\
\text { USA }\end{array}$ \\
\hline $\begin{array}{l}\text { North- } \\
\text { ern } \\
\text { Region }\end{array}$ & $\begin{array}{l}\text { Malathi- } \\
\text { on }\end{array}$ & $\begin{array}{l}\text { Malathi- } \\
\text { on } 96 \%\end{array}$ & ULV & OP & III & 200 & Very old & 34 & 0 & 6688 & 1988 & $\begin{array}{l}\text { Cynamid- } \\
\text { USA }\end{array}$ \\
\hline $\begin{array}{l}\text { Central } \\
\text { Region }\end{array}$ & Lindane & $\begin{array}{l}\text { Gam- } \\
\text { mexane }\end{array}$ & WP & OC & II & & Very old & 0 & 43000 & 0 & $?$ & $\begin{array}{l}\text { Cynamid- } \\
\text { USA }\end{array}$ \\
\hline $\begin{array}{l}\text { Western } \\
\text { Region }\end{array}$ & Lindane & $\begin{array}{l}\text { Gam- } \\
\text { mexane }\end{array}$ & WP & OC & II & & Very old & 0 & 31760 & 0 & $?$ & \\
\hline $\begin{array}{l}\text { Southern } \\
\text { Region }\end{array}$ & Lindane & $\begin{array}{l}\text { Gam- } \\
\text { mexane }\end{array}$ & WP & OC & II & & Very old & 0 & 15666 & 0 & $?$ & USA \\
\hline $\begin{array}{l}\text { Locust } \\
\text { Center }\end{array}$ & Lindane & $\begin{array}{l}\text { Gam- } \\
\text { mexane }\end{array}$ & WP & OC & II & & Very old & 0 & 53350 & 0 & $?$ & $\begin{array}{l}\text { USA } \\
\text { \&England }\end{array}$ \\
\hline $\begin{array}{l}\text { Central } \\
\text { Region }\end{array}$ & $\begin{array}{l}\text { Fentro- } \\
\text { thion }\end{array}$ & $\begin{array}{l}\text { Sumithi- } \\
\text { on Super } \\
100\end{array}$ & ULV & OP & II & 25 & Very old & 107 & 0 & 2675 & 1988 & $\begin{array}{l}\text { Sumito- } \\
\text { mo- Ja- } \\
\text { pan }\end{array}$ \\
\hline $\begin{array}{l}\text { Eastern } \\
\text { Region }\end{array}$ & $\begin{array}{l}\text { Fentro- } \\
\text { thion }\end{array}$ & $\begin{array}{l}\text { Sumithi- } \\
\text { on Super } \\
100\end{array}$ & ULV & OP & II & 25 & Very old & 30 & 0 & 750 & 1988 & $\begin{array}{l}\text { Sumito- } \\
\text { mo- Ja- } \\
\text { pan }\end{array}$ \\
\hline $\begin{array}{l}\text { Western } \\
\text { Region }\end{array}$ & $\begin{array}{l}\text { Fentro- } \\
\text { thion }\end{array}$ & $\begin{array}{l}\text { Sumithi- } \\
\text { on Super }\end{array}$ & ULV & OP & II & 25 & Very old & 72 & 0 & 1800 & 1988 & $\begin{array}{l}\text { Sumito- } \\
\text { mo- Ja- } \\
\text { pan }\end{array}$ \\
\hline $\begin{array}{l}\text { Western } \\
\text { Region }\end{array}$ & Dieldrin & $\begin{array}{l}\text { Ansoden } \\
30 \%\end{array}$ & ULV & OC & $\mathrm{lb}$ & 25 & Very old & 34 & 0 & 850 & 1988 & $\begin{array}{l}\text { Shell - } \\
\text { Holland }\end{array}$ \\
\hline $\begin{array}{l}\text { Southern } \\
\text { Region }\end{array}$ & Dieldrin & $\begin{array}{l}\text { Ansoden } \\
30 \%\end{array}$ & ULV & OC & $\mathrm{lb}$ & 25 & Very old & 479 & 0 & 11960 & 1979 & $\begin{array}{l}\text { Shell - } \\
\text { Holland }\end{array}$ \\
\hline $\begin{array}{l}\text { Central } \\
\text { Region }\end{array}$ & $\begin{array}{l}\text { Deltame- } \\
\text { thrin }\end{array}$ & Decis & ULV & Pyr & II & 25 & Old & 44 & 0 & 1100 & 1993 & $\begin{array}{l}\text { Rous- } \\
\text { selUclaf }\end{array}$ \\
\hline $\begin{array}{l}\text { Eastern } \\
\text { Region }\end{array}$ & $\begin{array}{l}\text { Deltame- } \\
\text { thrin }\end{array}$ & Decis & ULV & Pyr & II & 50 & Very old & 126 & 0 & 6300 & 1998 & $\begin{array}{l}\text { Rous- } \\
\text { selUclaf }\end{array}$ \\
\hline $\begin{array}{l}\text { Western } \\
\text { Region }\end{array}$ & $\begin{array}{l}\text { Deltame- } \\
\text { thrin }\end{array}$ & Decis & ULV & Pyr & II & 25 & Old & 62 & 0 & 1550 & 1993 & $\begin{array}{l}\text { Rous- } \\
\text { selUclaf }\end{array}$ \\
\hline $\begin{array}{l}\text { Western } \\
\text { Region }\end{array}$ & $\begin{array}{l}\text { Carbo- } \\
\text { sulfan }\end{array}$ & Marshal & ULV & Carb & II & 20 & Old & 28 & 0 & 560 & 1993 & $\begin{array}{l}\text { FMC- } \\
\text { USA }\end{array}$ \\
\hline $\begin{array}{l}\text { Western } \\
\text { Region }\end{array}$ & $\begin{array}{l}\text { Chlorpy- } \\
\text { riphos }\end{array}$ & Dursban & ULV & OP & II & 25 & Very old & 64 & 0 & 1600 & 1988 & $\begin{array}{l}\text { Fisons - } \\
\text { England }\end{array}$ \\
\hline $\begin{array}{l}\text { Western } \\
\text { Region }\end{array}$ & $\begin{array}{l}\text { Bendio- } \\
\text { carb }\end{array}$ & Ficam & ULV & Carb & II & 25 & Very old & 80 & 0 & 2000 & $?$ & Hoechst \\
\hline
\end{tabular}




\section{Responsibility for pesticide stocks}

Responsibility for pesticide stocks lies primarily with the owner of the pesticides, who might be the government or individual ministries (Ministries of Agriculture and Health); semi-governmental bodies (producer boards, farmer cooperatives); the pesticide industry; or the end-users (farmers). The owner should store and manage pesticide stocks in a proper and safe environmental sound manner, also takes the necessary precautions to prevent stocks from becoming obsolete. If any quantity of pesticides becomes obsolete, the safeguarding and environmentally safe technique disposal of the stockpile and cleaning up any related contamination should be the responsibility of the owner

\section{Guidelines for governments to prevent accumulation of obsolete pesticides I 6}

Prevention of accumulation of obsolete pesticides can be obtained by reduce and rationalize pesticide use, where possible, that can be effectively occurred by give priority to IPM in plant protection programs. In addition the proper management and evaluation of the requirement will led to careful selection of products and reduce the amount of purchased pesticides by. The adequate assessment by the owner of the pesticides and mainly by the government body represented by ministry of agriculture and ministry of health will avoid overstocking of pesticides and keep pesticide stocks as low as possible.

This assessment can be carried out by taking into accounts the answers of relevant considerations, such as; the necessity of the intended use of pesticides, availability of alternative approaches within the framework of IPM, involvement of the government in distribution of pesticide or can be obtained directly from the private sector, the effectiveness of the distribution system, the size of area that expected to require treatment, the application capacity, the available sprayers, equipment will be used for treatment, available protective clothing, and the number of qualified applicators, price of the pesticides will be distributed, capability of using the pesticides are currently kept in stock, and the storage capacity of the stores. Prevention of pesticide's accumulation and stagnation in pesticide sales are mainly the government responsibility. The government should review the regulations of pesticide distribution and handling. Distribution through government channels should be critically reviewed, less governmental involvement in distribution role will help to reduce the necessity to keep large pesticide stocks. Alternatively distribution should be carried out by private sectors and enhance it by more strict control in the private sector. Changing in prices should be controlled and also anticipating the effects of price changes. Large quantities of pesticides should not be stocked if there are plans to review. Subsidies or preferential tariffs of pesticides should be reduced or abolished. Strict regulation and controlling system by ensure in advance that products are effective will lead to avoid inappropriate products. In several countries, when such measures have been implemented they succeed to prevent the accumulation of pesticides.

\section{Disposal of obsolete pesticides I 7}

The environmental safe sound technique recommended for disposal hazardous waste is the high-temperature incineration. Generally the appropriate high-temperature incineration facilities are not available in the developing countries. In such cases the obsolete products should be shipped to special hazardous waste incineration plants in countries that are willing to accept the waste. It is necessary to re-package pesticides where they are found in the field, transport them overland to a major port and then by sea to a country where there is a dedicated hazardous waste destruction facility. The costs of incineration and the required logistical processes including re-packaging, shipment are high. In addition to the complicated and time consuming of the administrative procedures to comply with international conventions concerning the shipment of hazardous waste. FAO estimates the cost of these operations as betweenUS $\$ 3000$ and US $\$ 4500$ per ton, and resources needed for disposal of 241 tons in Saudi Arabia as summing of 723000 US\$. Alternative to high-temperature incineration facilities are the mobile incinerator or local cement kiln but they have their limitations and are often not applicable in a safe and/or cost-effective manner.

Sometime for small quantities of insecticides, other disposal methods such as chemical treatment or land filling after solidification may offer solutions for specific group of pesticides. Other methods are not recommended, and pesticides should never be disposed of by ordinary burying or open field burning.

\section{Acknowledgements}

None.

\section{Conflict of interest}

The author declares no conflict of interest.

\section{References}

1. Disposal of bulk quantities of obsolete pesticides in developing countries. FAO Pesticide Disposal Series 4.

2. Environmental Management Tool Kit for Obsolete Pesticides. FAO Pesticide Disposal Series 3.

3. Environmental Management Tool Kit for Obsolete Pesticides. FAO Pesticide Disposal Series 4.

4. Guidelines for the management of small quantities of unwanted and obsolete pesticides. FAO Pesticide Disposal Series 7.

5. Akogbeto MC, Djouaka RF, Kinde Gazard DA. Screening of pesticide residues in soil and water samples from agricultural settings. Malar $J$. 2006;5:22.

6. Dem SB, Cobb JM, Mullins DE. Pesticide residues in soil and water from four cotton growing area of Mali, West Africa. J Agricultural, Food and Environmental Sciences. 2007:1(1).

7. Okeniyia SO, Egwaikhideb PA, Akporhonorc EE, et al. Distribution of organochlorine and polychlorinated pesticide residues in water bodies of some rivers in northern Nigeria. EJEAFChe. 2009;8(11):1269-1274.

8. Dogheim SM, Mohamed el-Z, Gad Alla SA, et al. Monitoring of pesticide residues in human milk, soil, water, and food samples collected from Kafr El-Zayat Governorate. J AOAC Int. 1996;79(1):111-116.

9. Hajjar MJ. Study of organochlorine insecticide residues in soil of Damascus Ghota. J Damascus Unive For Agric Sci. 2001;17(1):80-88.

10. Al-Wabel MI, El-Saied MH, Al-Turki AM, et al. Monitoring of pesticide residues in Saudi Arabia agricultural soils. Research Journal of Environmental Sciences. 2011;5(3):269-278.

11. Ahmad R, Salem NM, Estaitieh H. Occurrence of organochlorine pesticide residues in eggs, chicken and meat in Jordan. Chemosphere. 2010;78(6):667-671. 
12. Hajjar MJ. The persisted organic pesticides pollutant (POPs) in the Middle East Arab Countries. Int J Agron Plant Prod. 2012;3(1):11-18.

13. Pesticide Storage and Stock Control Manual. FAO Pesticide Disposal Series 3.

14. Hajjar MJ. Health and environmental study in Coastal Area of Syrian Arab Republic GTFS/REM/070/ITA. FAO. 2005.
15. Baseline study on the problem of obsolete pesticide stocks. FAO. Summary of known obsolete pesticide stocks, July 2000. Saudi Arabia.

16. Prevention of accumulation of obsolete pesticide stocks. The problem of obsolete pesticides. FAO publication.

17. The Preparation of Inventories of Pesticides and Contaminated Materials. FAO Pesticide Disposal Series 1. 